\title{
Review on Diversity and Socio-Economic Contribution of Home Garden Agroforestryin Ethiopia
}

\author{
Tarekegn Deresse Beyene ${ }^{1 *} \quad$ Tariku Bachano Batayo ${ }^{2}$ \\ 1.MSC in Forest and Nature Conservation Scholar at Jimma University, College of Agriculture and Veterinary \\ Medicine, Department of Natural Resource Management \\ 2.MSC in Rural Development and Agricultural Extension Scholar at Jimma University College of Agriculture \\ and Veterinary Medicine, Department of Rural Development and Agricultural Extension
}

\begin{abstract}
Agroforestry is the major component of Ethiopian farming systems. Based on the components, the Home garden agroforestry practice is held to be more different due to the combination of annual and perennial crops, trees, and livestock, it has a crucial strategy in achieving sustainableforest conservation and agricultural land management that combines the production of food, wood, and livestock for rural livelihoods, harmonizing biodiversity, increase the stability of social-economic, cultural value and protect species provenance while sustaining the natural environment. On the other hand, it sequesters carbon and the home garden experience has multifunctional value in the country. The objective of the review first to assess the composition of species diversity and homegarden agroforestry contribution socioeconomic in Ethiopia and the second is to illustrate accessible prospect to improve the practice with advocate the dual purpose that is socioeconomic, environmentally and biodiversity conservation. The dominant species in various home gardens are economically viable as they have prevailed up to fulfill their demand. Women are more engaged than men for home garden activity which creates job opportunities and other social acceptance. There is also available indigenous and scientific knowledge that has to be managed and governed by concerned stakeholders. To improve sustainable home garden production system in the country, the government should have undertaken positive actions like agroforestry awareness creation, scale-up appropriate home garden components combination based on agroecological zone away in the country, provide support with good and multipurpose hybrid varieties, and formulate policy and strategy that encourage farmers to take home garden substitute as an alternative to secure food stability.
\end{abstract}

Keywords:Agroforestry, Biodiversity, Carbon sequestration, Home garden, Socioeconomic

DOI: $10.7176 / \mathrm{JNSR} / 12-7-04$

Publication date: April $30^{\text {th }} 2021$

\section{Introduction}

Ethiopia one of the developing countries and Increased demography and associated development activities in the last few decades have resulted directly and/or indirectly in the depletion of natural resource, which has, in turn, increased the pressure on homestead forest, especially in the developing countries to meet various needs of human beings. In this circumstance, correct inventory and assessment of a long-term strategy for conserving the endangered species and improvement of the existing species are crucial (Tefera, 2010).

Homegardens are commonly defined as A piece of land with a definite boundary surrounding a homestead, being cultivated with a diverse mixture of perennial and annual plant species, arranged in a multilayered vertical structure, often in combination with raising livestock, and managed mainlyby household members for subsistence production (Fernandes and Nair, 1986; Christanty, 1990; Hoogerbrugge and Frescos, 1993; Kumar and Nair, 2004; as cited in Tefara,2010). It is also defined as the area around the home where different vegetables and fruits are grown throughout the year to meet family nutritional requirements. (HKI,2001). The following common characteristics can be seen in the home garden (Kerstin, 1999). Place of proximity to home; Small in plot size; Cultivation of different vegetables, fruits, and other crops; Cultivation throughout the year; Production mainly for family consumption and sale if in excel; Managed by household members namely wife, husband, and children; and Use of low-cost input for cultivation(Kumar, B.M. and Nair, P.K.R.,2006).

Home garden is a land-use system involving deliberate management of multipurpose trees and shrubs in intimate association with annual and perennial crops and invariably livestock within the compounds of individual houses, the whole tree-crop, and the animal unit is being intensively managed by family labor (Kumar and Nair, 2006). It is furthermore one of the most important niches in which farmers feel confident to plant and maintain tree and shrub species on the other hand, from the conservation point of view, homesteads are the in situ and circa-situ conservation sites of a wide range of plant biodiversity (Makonnen et al., 2009). In the last few decades increased human population has resulted directly and indirectly in depletion of the natural vegetation which in turn increases the pressure on the home gardens especially in the developing countries (Alam and Maser, 2005).

Home gardening has proven to be an effective approach to improved household food security. The production of vegetables and fruits in the home garden contributes significantly to the increased consumption of 
these types of foods in many countries in Asia (Helen,2010).

The absence of formal or informal links between the home gardens on the one side and the national research and extension service on the other do not allow this important production system to benefit from the outcome of the research. Additionally, home gardens are not considered economically important or rather marginal and are often neglected in national and international agricultural research (Mekonen, 2010).

The commercial production systems at the end of the intensification gradient aim at maximum profitability and they are characterized as high input, open systems with low species diversity. On the other end, the rainforests are almost closed systems with very little input and high species diversity. In between, there are farming systems of intermediate complexity and species diversity that include different agroforestry and intercropping systems. In the past, monocropping systems were considered to be the most desirable end-stages of agricultural development since high production of the systems would contribute towards solving the problem of food shortage (Abebe., 2005).

Agroecological regions of Home Garden agroforestry practice in Ethiopiasince an outcome of different researcherchoose to carry out their study regarding the study area where it is suitable and potential of agroforestry home garden these are located Oromia and SNNP regions and a little are in Amhara which shows that the suitable agro-ecological zone is in the Southwestern and Southern part of Ethiopia. (Kumar andNair,(2006)

When we show the revision level of the home garden in the country, almost all works of literature are reviews about the south and southwestern part of the country. The home garden is significantly well known in Ethiopia, in general, and in the southern and southwestern part of Ethiopia in particular Since inset, coffee Catha and modules, are dominantly cultivated for economic value (Haile et al,2017) most researches deep looking on such species.

Appropriate management and significance of home gardens agroforestry practice has a great potential for contribution socioeconomic, improving food security, biodiversity conservation, and provides for ecosystem services in Ethiopia. The functions of home gardens are diverse, ranging from providing food and other necessary materials for subsistence to serving as a place to live and maintain a traditional lifestyle, cultural values, and social relations. The household relies on home garden plants for its food supply except for some supplementary produce coming from the crop fields. Diverse crops with different flowering, fruiting, and harvesting seasons and household animals fulfill this requirement. its also a source of construction materials, fuel, and beauty aids. Income generation is a growing function of home gardens, bringing a far-reaching impact to the nature of the agro-ecosystems.

The role of Home garden agroforestry practice goes beyond providing material and monetary benefits. The agro-ecosystems also serve several social functions. In the first place, they signal the status of the household. A well-managed homegarden, for example, is known to belong to a respected person of high status or a strong and clever farmer, even by a passerby. A young man who owns a good home garden has a better opportunity of success when soliciting a spouse. Since cultural activities such as religious rituals, wedding ceremonies, mourning, and dispute settlements take place within the home garden area, home gardens constitute a place for cultural exchange, teaching of rules, and transmission of traditions from generation to generation.

Home gardens are sites for the domestication of wild varieties, for example, germplasm for medicinal plants and fuelwood in the home garden largely comes from the natural ecosystem (Bennett-Lartey, et al., 2002; TestateHaylemariaet al., 2009 cited as in Agizeet al., 2013). Therefore, the natural ecosystems, which contain wild species, are the sources for plant species found in the home garden and cultivated fields. As a result, home gardens are important centers of experimental cultivation, plant introduction, and crop improvement as well as refuges for unique genetic diversity (Engels, 2002). The crops include cereals, fruits, vegetables, oils, pulses, roots/tubers, medicines, spices, condiments, fragrances, fumigants, crafts/implements, dyes, utility, ornamentals, and others (Farrington, 1999).

Generally, the main objective of this review is to show the diversity and home garden agroforestry benefit contribution socioeconomic, food security, harmonizing biodiversity, gender, and environmental resilience and home garden experience has multifunctional value in the country. This review may help the government body, scientific researchers, and students who have a big interest in this very important land-use system. The review could answers which scientific penetrates critical changes in the home garden.

\subsection{Objective of the seminar}

\subsubsection{General objective of the seminar}

To review diversity and home garden agroforestry benefit contribution socioeconomic in Ethiopia

1.1.2 Specific objective

* To review on diversity spices and home garden agroforestry in Ethiopia

* To review on home garden agroforestry benefit contribution socioeconomic in Ethiopia 


\subsection{Methods to Review}

The review is trying to the meeting point on the diversity and home garden agroforestry benefit contribution socioeconomic, food security, harmonizing biodiversity and environmental resilience and home garden experience has multifunctional value in the country. Existing extensive types of literature which are concentrating on home garden Agroforestry practice and related documents were reviewed. the secondary data were collected from published were books, journals, articles,online materials, reports, and other relevant published documents. Website (Google) was also the keyway of carried out to access other relevant publications.

\section{Diversityand socioeconomic contribution Home garden Agroforestry in Ethiopia. \\ 2.1 Home Garden:}

This represents land-use systems involving deliberate management of multipurpose trees and shrubs in intimate association with annual and perennial crops and livestock within the compounds of individual houses. The whole tree-crop- animal units are being intensively managed by family labor. Home gardens can also be called a Multitier system or Multitier cropping. Home gardens are highly productive, sustainable, and very practicable. Food production is the primary function of most home gardens. Many species of trees, bushes, vegetables, and other herbaceous plants are grown in dense and in random or spatial and temporal arrangements. Most home gardens also support a variety of animals. Fodder grass and legumes are also grown to meet the fodder requirement of livestock. In a research conducted by Edmund (2005), he discovered that one of the agroforestry practices used in the South-eastern State of Abia includes multi-story home gardening and border planting. He highlighted some of the reasons why the method is used more, such as the security it provides in food production, the variety of crops obtained, the capacity to boost soil fertility, and the much-needed income.

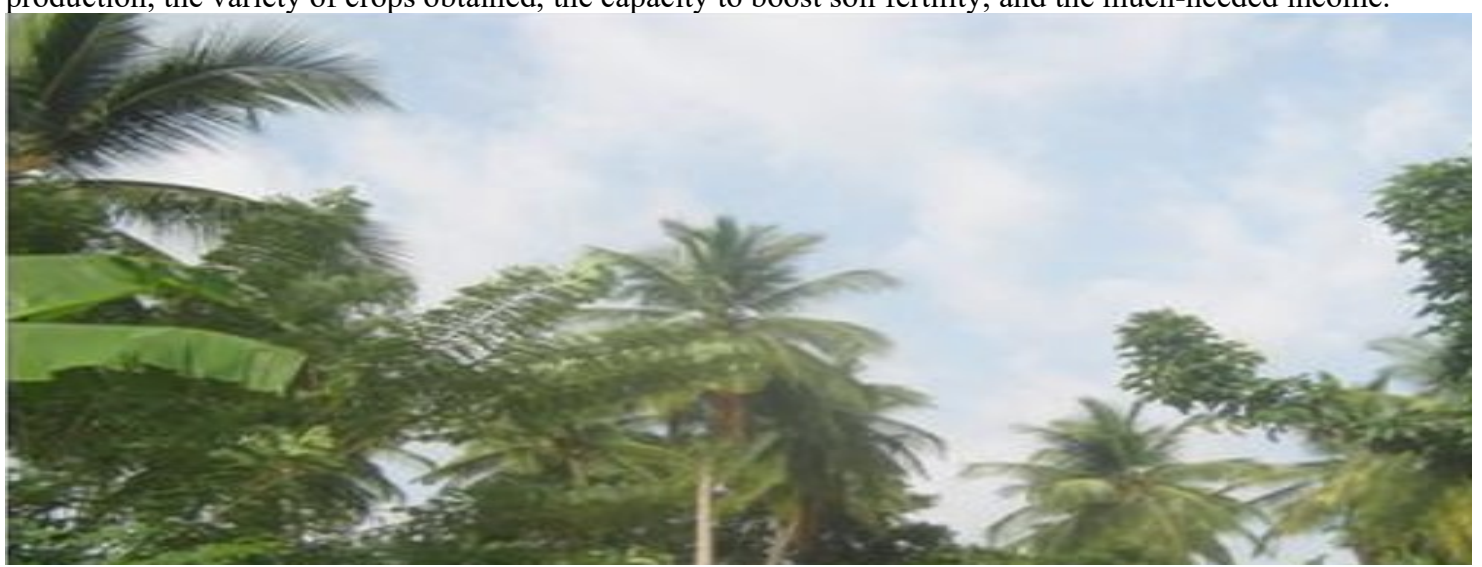

Figure 1: Typical example of Home garden

Source: The role of agroforestry in environmental sustainability (Sobola., 2015.)

\subsection{Traditional homegarden agroforestry}

According to World Agroforestry Center, agroforestry is a dynamic, ecologicalbased natural resources management system through integration of trees into rangeland and farmland to diversify and sustain production for the increasing socio-economic and environmental benefits for all land users at all levels (Atanganaet al., 2013; ICRAF, 2006).Home garden AgroforestryTraditional agroforestry land use should be viewed as a household strategy for providing food, fuelwood, and fodder that could serve as a model for sustainable forestry and agricultural practices (Badege\& Abdu, undated). It has been practiced in Ethiopia since time immemorial by villagers on farmlands. It is recognized worldwide as a sustainable system characterized by the production of multiple species closely arranged in several overlapping canopy layers and association with livestock (Peyre et al., 2006). These integrated land-use systems are believed to enhance agriculture due to the association between multiple crops and trees on one hand, and various ecological and economic benefits on the other. According to Tesfaye (2005) home garden agroforestry in SNNPRS is characterized by the unique combination of two native major perennials enset(Sensateventricosum), and coffee (Coffee arabica) which grow in association with food crops, various trees, and livestock in a multilayer story agroforestry system (Tesfaye et al., 2010; Almaz, 2001 cited as inGebrehiwot, 2013. ).

The traditional agroforestry home garden is one of the agroforestry practices that has been ingrained in the traditions and culture of local communities and is widely distributed in the tropics (Miller et al., 2006). The knowledge gained over time from traditional agroforestry home gardens is the basis for the development of agroforestry practices employed by farmers in many parts of the world today. These home gardens contain a variety of species that represent social and traditional aspects of various societies, where the selection of species 
and their arrangement and management, varies between and within home gardens (Mendez, 2000; as cited in Tamirat, 2017).Traditionally managed agroforestry practices have the potential to connect and integrate protected areas with the surrounding landscapes and mediate the livelihood need of people within the conservation goal of protected areas (Ashley et al., 2006). Thus it provides the potential to reduce land-use pressure and improve rural livelihoods in human-dominated landscapes and at the same time conserving a large proportion of biodiversity (Bhagwat et al., 2008b).

\subsection{Home gardens of Ethiopia}

The importance of agroforestry cannot be overemphasized, as it has several advantages in the provision of food and other basic needs (i.e. fuelwood, staking materials, fibers, timber, medicinal concentrates, oils, fruits, and fodder for animals) for a large proportion of the rural population as well as its role in soil fertility restoration and the control of weeds in addition to amelioration of environmental degradation. Agro-forestry practices are being increasingly advocated as possible remedies and had been claimed, to have the potential of improving agricultural land-use systems, providing lasting benefits, and alleviating adverse environmental effects at the local and global level. Adedire, 2004; Adekunle, 2005; and Ode ,2008). agreed that agroforestry can provide new and useful solutions to many of the adverse consequences of human land use, including increased diversification of agricultural production system, increased yield of crops and livestock, reduction of non-point source pollution, and increased rural development by contributing to an ecosystem-based management system, that guarantees sustainability and environmental quality. Agroforestry should therefore be seen as a system that addresses the declining quality of the environment, including the soil, while also increasing the variety of products by the farmer. This will not only increase the farmers' income but also help ensure food security and balance. The retention of trees in farming systems has been recognized to increase crop output in the semi-arid region of Adamawa state (Amadi et al; 2003). Ajake (2012) also recognized the function of forest trees in terms of income generation, good medicare, employment generation, raw materials, and provision of food among others. Agroforestry is increasingly promoted for restoring forest, degraded environment, reducing greenhouse gases, and gaining other co-benefits, ( Richard et al; 2009)

(Richard et al; 2009) also pointed out some of the key benefits that agroforestry puts into sustainable development programmers, these include Biodiversity conservation, environmental (watershed) Protection, and Climate change mitigation and adaptation. It was therefore viewed as being useful in promoting afforestation /reforestation and in the unfurling mechanism for forestry development: "Reduction of Emissions from Deforestation and forest Degradation (REDD)" has also been recognized, as well as, meeting (inter)national climate change objectives. Agroforestry is also being known for, its role in traditional employment generation, thus it can deliver several benefits (e.g. income generation for poor farmers, environmental and ecosystem stabilization including control of desertification and deforestation)

\subsection{Home gardens of Southern Ethiopia}

Extensive areas of traditional agroforestry home gardens exist in the south and south-western parts of Ethiopia. Most of these gardens are located at altitudes of 1500-2300 meters above sea level where moisture and temperature conditions are favorable for agriculture. These gardens are characterized by a unique combination of two native perennial crops: enset and coffee. Inset (Ensetventricosum (Welw.) Cheesman) is a herbaceous multipurpose crop, and a staple food for about 10 million people in the region. Coffee (CoffeeArabica.) is mainly used as a cash crop, but also for household consumption. Other components of these multispeciesagroecosystems include chat (Chataedulis (Vahl.) Forssk.ExEndl.), a mild stimulant, root, and tuber crops, fruits, vegetables, cereals, spices, and other crops. Moreover, livestock is kept in the gardens and different tree species are grown to serve productive as well as ecological functions. These gardens are also known as 'enset-coffee home gardens after the two major components. The area of enset-coffee homegardens in Southern Ethiopia is not known. Some reports have provided estimated areas of the major crops in isolation, but the agroforestry systems where coffee and enset are grown in association with other crops and trees is not known. According to BODEP (1996), a total area of 1.89 million hectares of land is under cultivation in the Southern Nation's Nationalities and Peoples' Regional State (SNNPRS). Out of these, the area of coffee and enset, and the other crops grown in association with them (such as fruits and vegetables, root and tuber crops, and pulses) is estimated at 576,000 hectares (BODEP, 1996). The home gardens constitute most of these areas.

Most of these home gardens have evolved from forests. Farmers maintain the upper story trees and clear the undergrowth to open up space for planting enset, coffee, and other crops. Gradually, more species and varieties of crops and trees are introduced. Partial harvesting of the upper story trees also takes place to obtain wood and to create the favorable growing condition for the other crops.Presently, most of the forests are used up and there is an increasing shortage of land. In these situations, some farmers are observed to convert their plots of grazing land into multispecies complex systems. The enset-coffee home gardens have been stable agricultural systems for centuries supporting very dense populations of up to 500 persons per square kilometer (CSA, 1996: Kippie, 
2002). The diversity of the systems, and the ability of enset to produce a relatively large amount of food per unit area and time (Admasu and Struik, 2001), could be the main factors that contributed to this stability. Moreover, due to its multi-annual production time and its flexibility in harvesting, enset is an ideal crop to overcome food shortage in drought times (DesalegneRahmato, 1995). Coffee, which is produced in these predominantly smallholder agroforestry systems is also the major foreign currency earner of the country. Obviously, these agroforestry systems ensure food security in the areas, play a significant role in the regional and national economies, and also contribute to environmental resilience.

\subsection{Agro climatic based homemade agroforestry practice in Ethiopia}

The diverse climatic conditions range from the hot and dry desert in the lowland areas to cold and humid highlands. There are different authors three agro-ecological zones with different climates linked to altitude, rainfall, and temperature (Table 1 \& Figure 2). The first is the Degaagro-ecological zone (high lands) with a wet and cool temperate climate, where farmers mainly practice silvopastoral agroforestry with enset, cereals such as barley, and wheat, as well as vegetables as the main agricultural products. The second is the WoynaDegaagroecological zone (semi-highland) with moist to humid, warm subtropical climate, where the traditional agroforestry systems as home gardens and shade-grown coffee are the common practices. Enset is the dominant crop growing both in the WoynaDega and the Degaagro-ecological zone with differences in its spatial arrangement. The third is the Qollaagro-ecological zone (low land) with dry and hot tropical climate; where agriculture is dominated by annual crops such as maize, sorghum, and haricot bean, but pastoralism is also an important economic activity (Tesfaye, 2005). The natural vegetation ranges from the evergreen Afromontane forests (1500 to 2600 m.a.s.1,) via transitional rainforest (500-1500 m.a.s.1.) to the dry semi-deciduous forest (450 to 600m.a.s.1.) (Tadesse et al., 2014).Afromontane forests arethe natural habitat for the wild coffee (Coffee arabica), which makes this forest type important for conserving both the genetic diversity of coffee and the livelihoods of the rural people who depend on thesubsistence production of coffee (Senbeta and Denich, 2006; Silvestrini et al., 2007; Tadesse et al., 2014)

\subsection{Description of three agro-ecological zones in Sidama}

\begin{tabular}{lllll}
\hline No & $\begin{array}{l}\text { Agro-ecological } \\
\text { zone }\end{array}$ & Altitude & $\begin{array}{l}\text { Annual rainfall, } \\
\mathbf{m m}\end{array}$ & $\begin{array}{l}\text { Annual } \\
\text { temperature, } C^{\circ}\end{array}$ \\
I & Dega & $2500-3500$ & $1200-1800$ & $10-15$ \\
II & Woyna Dega & $1500-2500$ & $1000-1800$ & $15-20$ \\
III & Qolla & $500-1500$ & $400-800$ & $20-25$ \\
& & & & \\
& & &
\end{tabular}

Figure 2: Description of three agro-ecological zones in Sidama(Source: Tesfaye 2005)

\subsection{Structure and composition of home gardens}

Tropical home gardens are characterized by vegetation layers (stories), imitating the tropical forest structure. The top story consists of a canopy of tall trees which reduces radiation and mechanical impact of rainfall, creates a relatively constant micro-climate in the lower layers, and through leaf fall contributes to the maintenance of soil fertility. The lower layer features staple food and fruit production (e.g. banana, mango, papaya, etc.,) followed by bush level growth (e.g. cassava, maize,

Peppers, etc.) in the third layer. In-ground and ground-covering species (roots and tubers and others) form the last layer while climbing species transverse the lower stories (Fernandes and Nair, 1986).

Even though the spatial arrangement of the species seems to lack order and pattern, compatible species are often mixed (Fernandes and Nair, 1986). Moreover, spatial arrangement in these systems often reflects their functional adaptation in a multitude of factors including utilization of plant-symbiotic relationships through mixed cropping (Inez, 1987). The structure and composition of home gardens differ across sites depending on 
the ecological setting and socioeconomic functions within different household economies (Wiersum, 1982; Christanty, 1985; Fernandes and Nair, 1986; Soemarwoto and Conway, 1991)

Home garden agroforestry represents a high degree of compositional, structural, and functional diversity playing key roles in on-farm conservation and ensuring environmental well-being while contributing to livelihood support systems (Habtamu\&Zemede 2011). Mainly indigenous tree species such as Ficus spp., Cordiaafricana, Croton macrostachyus,andMillettiaferruginea and fruit trees such as mango (Mangiferaindica) and avocado (Perseaamericana) from the upper story. Dominant species such as coffee (Coffeaarabica L.), an evergreen shrub, and enset (Enseteventricosum), a large non-woody evergreen perennial herb, form the middle story, as illustrated in photo 4 . The low story is often occupied by vegetables, spices, and herbs. The coffee component decreases with altitude, but enset is found at all altitudes (Gebrehiwot\&Maryo 2015). The architectural design of this system helps to use space effectively in such a way that the combination enhances beneficial interactions and nullifies adverse ones. In some cases, the productivity of crops in an open field is far below productivity in the combination. For instance, coffee can be grown in an open field as a monocrop in some parts of Ethiopia; however, the quality, as well as quantity, is considerably lower than that of the coffee on an integrated farm. Indeed, the other typical characteristic of Gedeo home garden agroforestry is its productivity on slopes as steep as 80\% (EPA 2004), which is steeper than the optimal slope for agriculture.

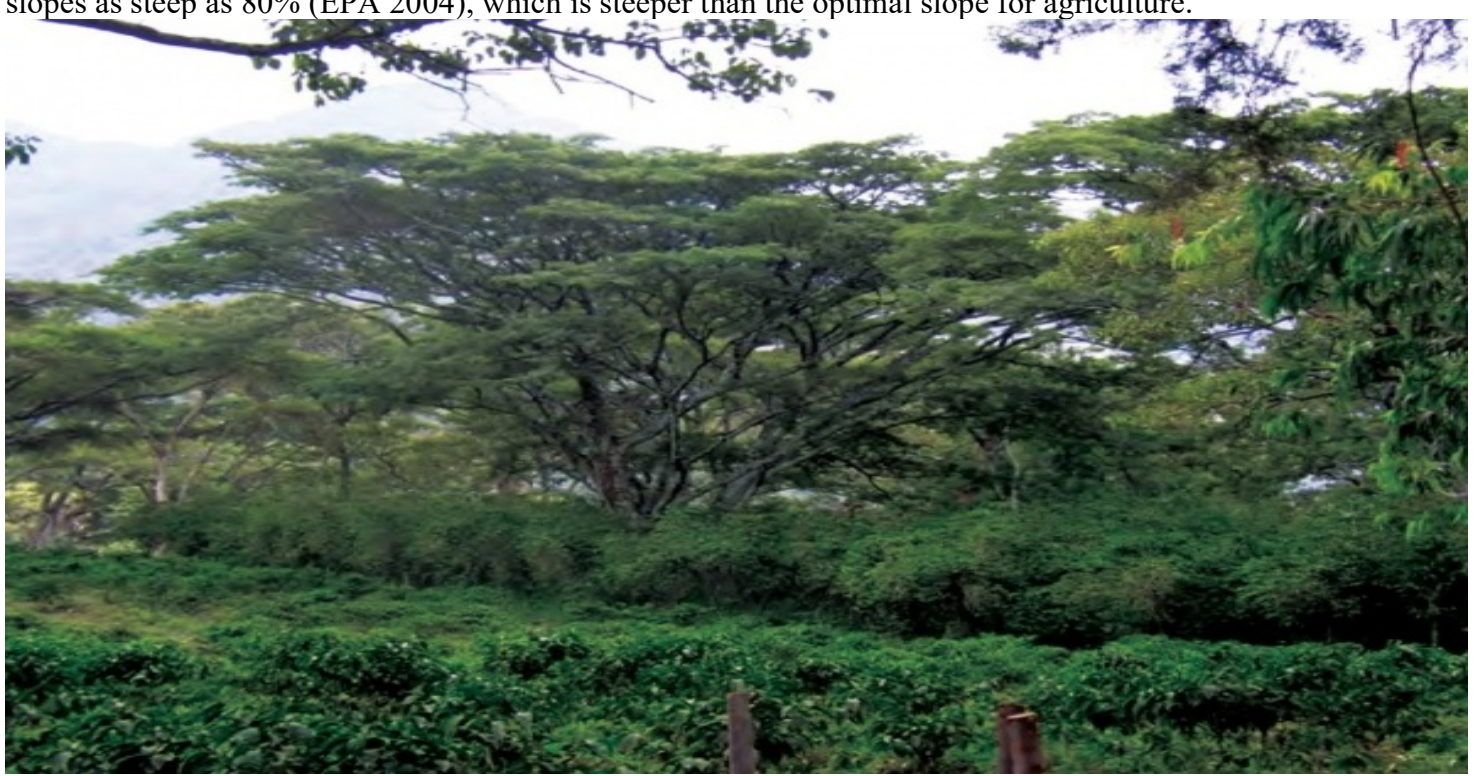

Figure 3: coffee-based agroforestry in Gedeozone(Bishaw et al. 2013)

\subsection{Homegarden in Species diversity}

Agroforestry practice is more concentrated on species diversity with their role that resulting inthe development of the practice. Tropical home gardens contain a high diversity of trees, shrubs, vegetables and crop species, animals (Belachew et al.,2003).

The agroforestry home garden is a cultural and traditional locally developed agroecosystem practice with rich biodiversity in the south and southwest parts of Ethiopia et al., 2006). It has been developed through maintaining indigenous trees or by planting trees on farmlands, grazing fields, around the individual household, as a shelter for humans and livestock, windbreak, live fence, and shelterbelt (Tsegazeaber, 2012). Agroforestry home gardens are highly diverse in species composition, thereby delivering multiple products and services essential for food security, sustaining livelihoods and wellbeing of rural households in Ethiopia (Admasu and Struik, 2002b; Almaz et al., 2002; Almaz and Nieho, 2004; Gebrehiwot et al., 2016; Tesfaye et al., 2009). For example, only in four sub-districts in southern Ethiopia, Tesfaye (2005) reported 198 plant species (114 tree and 78 food crops); Feleke (2011) and Kebede (2010) identified more than 100 different plant species, including trees, shrubs, herbs, and climbers. The presence of the two dominant perennial 'keystone species, enset (Sensate ventricosum) and coffee (Coffee arabica), which together usually cover more than $60 \%$ of the cropland make this farming practice unique and attractive (Admasu and Struik, 2001). Enset is planted in the living quarter very close to individual houses together with vegetables, pulses, roots, and other food crops; and then mixed with shade-grown coffee, mixed with native trees, fruit trees, and various undergrowth species. Within enset production systems, seven to ten million people cultivate enset as a staple food, or as a co-staple with cereals and root- and tuber crops (Admasu and Struik, 2002a). Brandt et al. (1997) concluded that enset has been used as a food crop for thousands of years in Ethiopia, and is an important staple food that supports over $20 \%$ of the 
population living in the southern and southwestern parts of the country (Figure $1 \& 2$ ). Small areas of the front yard of houses are used for keeping livestock and for social gatherings. The edge of the living quarter and roadsides are mainly used for Eucalyptus woodlots. In addition to their shade and timber value, the shade trees are used for hanging traditional beehives for honey production.

\section{Outcome}

\subsection{Farm-level diversity and density of trees and shrubs}

In total 120 trees and shrub species were recorded in the agroforestry home gardens of Sidama Zone, Southern Ethiopia. The frequency of occurrence of the species across home gardens was rather variable, but six species occurred in over $85 \%$ of the home gardens. Coffeaarabica L. was the most frequent species occurring in all (100 $\%)$ of the farms. It is followed by Cordiaafricana Lam. (95.1\%), Eucalyptus. camaldulensisDehn. (92.4\%), Perseaamericana Miller. (86 \%), Milletiaferruginea (Hochst.)Baker (85\%), and Euphorbia candelabrum Trem.\&Kotschy. $(85 \%)$. On the different, 19 tree species were very rare each occurring only in one of the farms. Out of the total number of woody species, $74.2 \%$ were indigenous.

\subsection{Diversity of trees at farm units}

Tree species richness of the different farm units varied widely (Table 2). The coffee units, which cover the largest proportion of the farms (36.6\%), are the richest in tree species (13.3) followed by enset (8). Coffee units/fields, even when small, are associated with more trees but units of pineapple, khat, sugarcane, sweet potato and maize of any size always have few tree species or no trees a

Table 1: Mean number of tree species associated with the different unit types

\begin{tabular}{lcc}
\hline Farm spatial units & $n$ & Number of speci. \\
\hline Home and grazing & 144 & 7.20 \\
Enset & 142 & 8.03 \\
Coffee & 140 & 13.27 \\
Woodlots/trees & 69 & 7.57 \\
Maize & 59 & 4.08 \\
Khat & 42 & 2.46 \\
Sugarcane & 28 & 2.64
\end{tabular}

Tree species composition varied strongly among farms. A DCA showed large differences in species composition among individual farms, and similarity in the composition of tree species decreased with increasing geographical distance and elevation difference. Part of the (dis)similarity among farms is related to the home garden type. In the DCA the different types of enset-coffee home gardens spreaded. Tree species richness varied significantly $(\mathrm{P} \backslash 0.001)$ across homegarden types: the subsistence-oriented enset-coffee-maize-sweet potato type had the highest number of tree species (25.3) followed by enset-coffee-maize type (24.4). Also, the density of trees varied significantly with enset-coffee-maize type home gardens having the highest density of trees (636 trees ha-1). The remaining two cash crop-oriented homegarden types have the lowest number of tree species and tree density.

What factors influence diversity and density of trees in the home gardens?

Physical and socioeconomic factors influenced farm level species diversity and density of trees Farms located near roads had fewer tree species, lower diversity, and lower density. The total number of trees, as well as their density, increased with elevation. Tree species richness and number of trees of farms increased significantly with farm size. As the area of woodlots increased, the density of trees increased significantly but the diversity and Evenness decreased. Distance to local markets did not have any effect on the diversity and density of trees.

Agricultural biodiversity refers to the variety and variability of plants, animals, and microorganisms at genetic, species, and ecosystem levels involving the whole agro-ecosystem that is actively managed by farmers (Cromwell et al., 1999). Tropical home gardens contain high diversity of trees, shrubs, vegetables and crop species, animals, including spatial arrangement of these components The high diversity of species in homegardens, have a wide socioeconomic and ecological roles including the production of food and a wide range of other products such as firewood, fodder, spices, medicinal plants and ornamentals (Christanty, 1985; Marten and Abdoellah, 1988; Gliessman, 1990) and avoidance of environmental deterioration commonly associated with monocultural production systems Fernandes and Nair,1992), largely due to effective nutrient cycling and relatively small hazard for leaching and soil erosion (Wiersum, 1982; Jensen, 1993). Since homegardens are typically spaces of crop diversity, improving homegardening requires the optimal use of local 
agrobiodiversity, as well as the dynamic integration of additional crops and crop varieties with specific values and uses. Many neglected crops, such as the enormous diversity of African leafy vegetables, constitute important plant genetic resources for developing home gardening in Africa.

The introduction of new crops is generally a feasible and desirable strategy, as home gardens boast a notable degree of flexibility with low agroecological impact. There are many crops suitable to expand the agrobiodiversity base of home gardens, including leafy vegetables, fruit vegetables, root crops, and legume crops. The consideration of seed access and seed multiplication aspects is also relevant for the effective and continued development of home gardens (FAO, 2001). Homegardens are typically spaces with rich agrobiodiversity, vegetable crops, and fruit trees.

\subsection{Socioeconomic aspects and Importance of Agroforestry}

Over long periods in the history of land use in highly populatedhumidtropicallowlands, home gardenshave remained as engines of economic and social development. Although productivity compared to intensive monocultures was modest, diversified production and income generation in perpetuity were intrinsic features of tropical home gardens. Planting and maintaining home gardens also reflect the culture and status of the household, especially the women, in the local society. In many places, women play a vital role in the design and management of these land-use systems(e.g., Kerala, Central Java, and West Sumatra) further underscores this point (Menon et al. 2002; Soemarwoto and Conway 1991). Many activities such as vegetable growing,harvesting the products (fruits, nuts, vegetables, and medicinal plants), fuel collection,and animal rearing,especially in the smaller gardens are exclusively the domain of females, withor without assistance fromthemale members ofthe family. The possibilityof genderequalityforparticipating in garden management and sharing of benefits is perhaps one of the major stimuli for continuedhousehold security enjoyed by home gardeners for generations. Some other aspects of socioeconomic sustainability such as household nutritional security and generation of income have already been discussed. The whole aspect of sustainability of home gardens seems to be fertile grounds for social science research. Many activities such as vegetablegrowing,harvestingthe products (fruits, nuts, vegetables, and medicinal plants), fuel collection, and animal rearing,especially in the smaller gardens are exclusively the domain of females,with or withoutassistance fromthemale membersofthe family. The possibilityof genderequalityforparticipating in garden management and sharing of benefit is perhaps one of the major stimuli for continuedhousehold security enjoyed by home gardeners for generations. Some other aspects of socioeconomic sustainability such as household nutritional security and generation of income have already been discussed. The whole aspect of sustainability of home gardens seems to be fertile grounds for social science research.

Oram (1993) reported that agroforestry provides a wider range of products, more secure subsistence, or more cash income from wood products to enable the farmer to buy food. Nair (1993) found that in tree home gardens, the production is for home consumption, but any marketable surplus can provide a safeguard against future crop failures and security for the interval between the harvests (e.g. rice in Java and Sri Lanka, coffee and maize in Tanzania, coconut and rice in South Western India). Some important service roles of agroforestry are soil conservation, either erosion control (presence of a permanent soil cover, barrier effect against runoff), soil fertility maintenance (incorporation of organic matter into the soil, nutrient pumping from the deep layers of the soil through the tree's roots, these nutrients then improve the crops through litter and mulch, nitrogen fixation) or soil physical properties maintenance (Young, 1989). He indicated that the creation of a microclimate, which can be beneficial to certain plants or animals, for example, modifications of light, temperature, humidity, or wind, and can also help fight weed proliferation. Agroforestry plays a better role in increasing agricultural productivity by nutrient recycling, reducing soil erosion, and improving soil fertility, and enhancing farm income compared with conventional crop production (Kang and Akinnifesi, 2000). Furthermore, agroforestry also has promising potentials for reducing deforestation while increasing food, fodder, and fuelwood production (Benge, 1987and Young, 1997). Some of the benefits that agroforestry offers are: soil-fertility improvement, provision of wood products (fuelwood, poles, timber, fruits, medicines, etc.), improved beekeeping, control of erosion, stabilizing of river and stream banks (i.e. prevention of siltation), improvement of water infiltration into the soil, shrubs can act as live fences against livestock and human beings, trees and shrubs can contribute to better microclimate (shade, windbreak, etc.,) and provision of fodder, especially in the dry season.

According to (Kumar, and Nair, 2004.) someof the economic, social, and/or cultural foundations of homegardening, in comparison with other farmingsystem components under similar situations are listed below:

$\checkmark$ Low capital requirements and labor costs - suitable for resource-poor and small-holder farming situations

$\checkmark$ Better utilization of resources, greater efficiency of labor, even distribution of labor inputs, and more efficient management

$\checkmark$ Diversified range of products from a given area and increased value of outputs

$\checkmark \quad$ Increased self-sufficiency and reduced risk to income from climatic, biological, or market impacts on 
particular crops/products

$\checkmark$ Higher-income with increased stability, greater equity, and improved standards of living

$\checkmark$ Better use of underutilized land, labor, or capital, besides creating capital stocks to meet intermittent costs or unforeseen contingencies

$\checkmark$ Enhanced food/nutritional security and ability to meet the food, fuel, fodder, and timber requirements of the society

$\checkmark \quad$ Increased fulfillment of social and cultural needs through sharing or exchange of produces and recreational opportunities

$\checkmark \quad$ Better preservation of indigenous knowledge.

\subsection{Ecological sustainability: Biodiversity}

The wide spectrum of plant species creates the multi-layered vegetation structure in home gardens, which is responsible for many benefits and advantages of the system and, thus, for its sustainability. Plant and animal diversity is considered a sustainability indicator (Torqueblau, 1992)

\subsection{Home garden contribution to the family health}

It has been established that even moderate and mild energy malnutrition contributes to child mortality, and micronutrient deficiencies are associated with increased risk of child and maternal mortality (Kiss et al., 2001). Home gardens are one strategy for addressing malnutrition and micronutrient deficiencies. Even though animal products are the best source of micronutrientsvegetables and fruits may be the only source of micronutrients that are reliably available to poor households (Talukder et al., 2000; Bloem et al., 1998; Reddy, 1995). Several studies have been reported that home gardens are producing a high percentage of fruits and vegetables consumed by home gardening families. Although it is relatively straightforward to determine whether a home gardening program has increased the production and consumption of fruits and vegetables, it is not a simple matter to determine the impact of home gardening on nutritional status (HKI/AP, 2003). Nevertheless, several studies have concluded that home gardens are associated with better household nutrition. One of the most important vitamins supplied by homegardens is vitamin A, which is essential not only for healthy eyes but also for the protection of infectious diseases such as measles (Soleri et al., 1991). While the homegarden is the most unnoticed production system, it provides not only food but also income and aesthetic, spiritual, and psychological benefits for the poor and marginalized families in the developing world (Boncodin et al., 2000). According to Christianity (1990), cultural values should also be taken into account. The disappearance of home gardens and the species diversity in them can lead to a loss of social, traditional, and cultural values. Nevertheless, the economic contribution has been largely underestimated. Ninez (1986) considers that the total production of home gardens is equivalent to $60 \%$ of the rice production value while (Velez, 1997), states that a rural home garden contributes on average, $13 \%$ of the daily household's food budget which is $22 \%$ of the average household daily wage. In addition to their usefulness in combating vitamin, A deficiency home gardens are associated with some other nutritional benefits, some of which have tended to be overlooked (Marsh, 1998). Homegardens have been reported to provide 18-40\% of household calories on Java (Christanty, 1981 and Stoler, 1978 cited in Hoogerbrugge and Fresco, 1993) and 50-58 \% of the recommended daily allowance for calories in the Philippines (Sommers, 1978; cited in Christianity, 1990). In many areas around the world, a significant portion of the household nutrition requirements is fulfilledfrom their home gardens that encompass multiple food crops (Caron, 1995; Mendez et al., 2001; Vogl et al., 2002).

It is realistic, however, to call for extending ecological and economic studies to understand, value, and evaluate such time-tested systems as home gardens, so that these systems are recognized deservedly in policy discussions at regional and national levels, and the experiences from these systems could be exploited for the design of another sustainable land. 


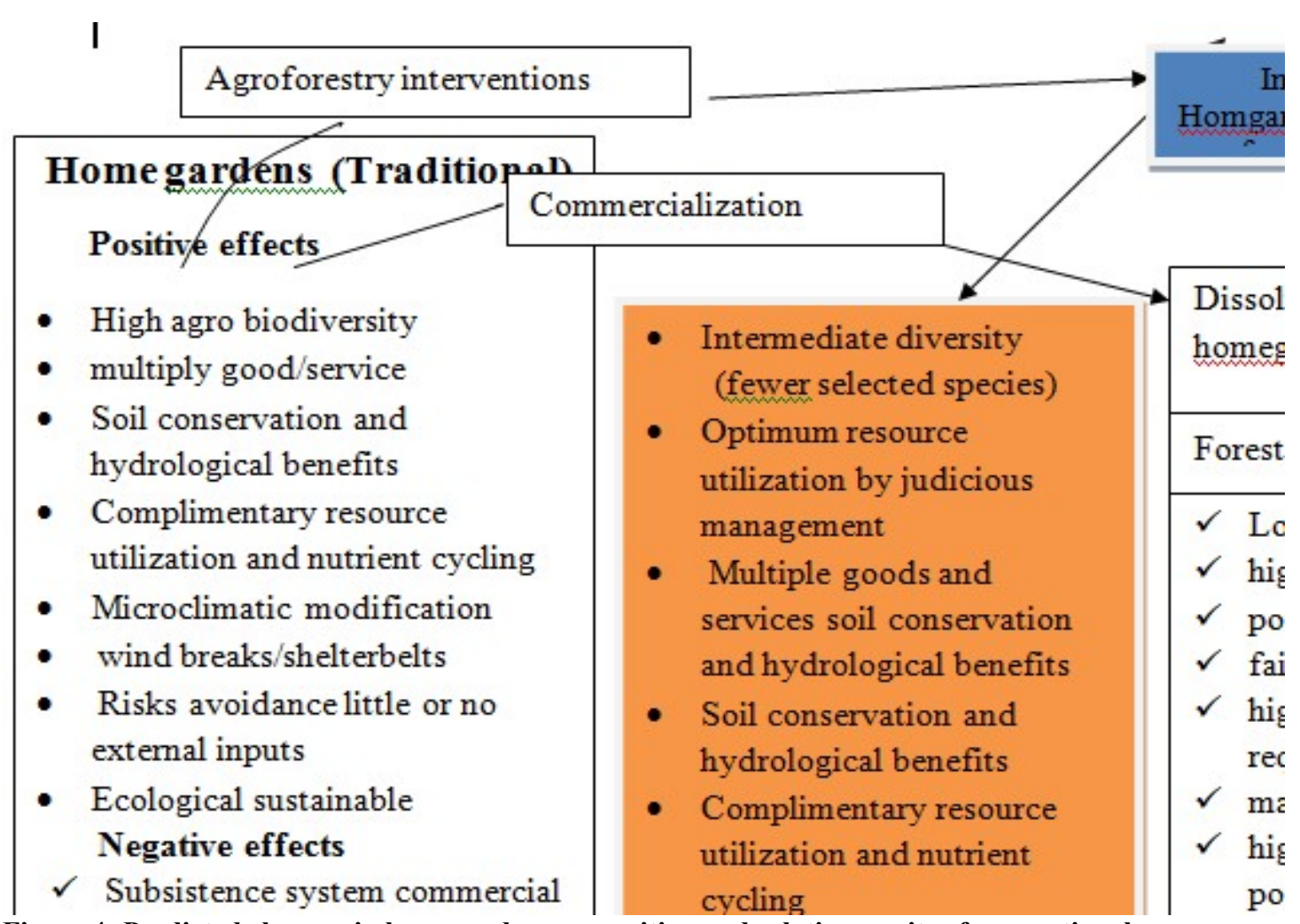

Figure 4: Predicted changes in homegarden composition and relative merits of conventional

\subsection{Home garden products Marketable}

Marketed and Marketable Homegarden Products Its surplus product can sell to the market when the market distance seems to closer to the farmer's garden which helps them to get money from marketed products. The income which is obtained from the marketed product will help them to purchase another food type to satisfy their food utilization. Some researchers found that the major cash crops which grow in the country's home garden are cabbage, enset, lumen, orange, papaya, mango, and avocado, etc. some other also found like Coffearebica, Catha edulis, Milletiaferruginea, Cordiaafricana, Croton macrostachy, etc. are trees those are more useful for improving soil fertility and capabilityconserve soil moisture(Alemu MM,2016).

\subsection{Homegarden agroforestryMarket and gender}

In traditional homegarden agroforestry, crop production is primarily for subsistence, not for the market. However, women are responsible for selling surplus food crops, fruits, vegetables, and dairy products to supplement their household food supply while livestock, poles, and timber have been traded by men. The expansion of khat and eucalyptus resulting in reduced area share of food crop and dairy products has also limited women's opportunities of trading and marketing such farm products. Meanwhile, men`s market opportunities and control through trading of khat, and eucalyptus have increased in the study region. The market survey and observations showed that a large number of women doing trading in the local market, but most of them are not farmed, women. Further, they are mainly involved in "petty trading" such as buying and selling small-scale products for subsidizing the food supply in their household. Men are involved in livestock trading and wholesale and large-scale trading of food crops such as potatoes, avocado, and trading of items besides khat and eucalyptus in the market. It was also observed that the new khat and eucalyptus market and the well-organized market chain that connected farmers, traders, and brokersare dominantly controlled by men and women are strongly prohibited from the business (Gebrehiwot,2013).

Home garden agroforestry CharacteristicsEthiopia is one of the tropical countries in which home garden agroforestry is ubiquitous in the highlands. Agroforestry is the major component of Ethiopian farming systems. Based on the components, Gedeo agroforestry is categorized as the agrosilvo pasture type (Nair 1993) where trees, crops, and animals are part of the system. The three common types of agroforestry practices are home garden, parkland, and woodlot (Akliluet al., 2015). In the cereal crop-based farming system, staple food crops such as barley, tiff (Eragrostistef, a small grain), wheat, and maize are grown in the outer farm with trees while vegetable species and fruits are grown in the home garden. This type of agroforestry 


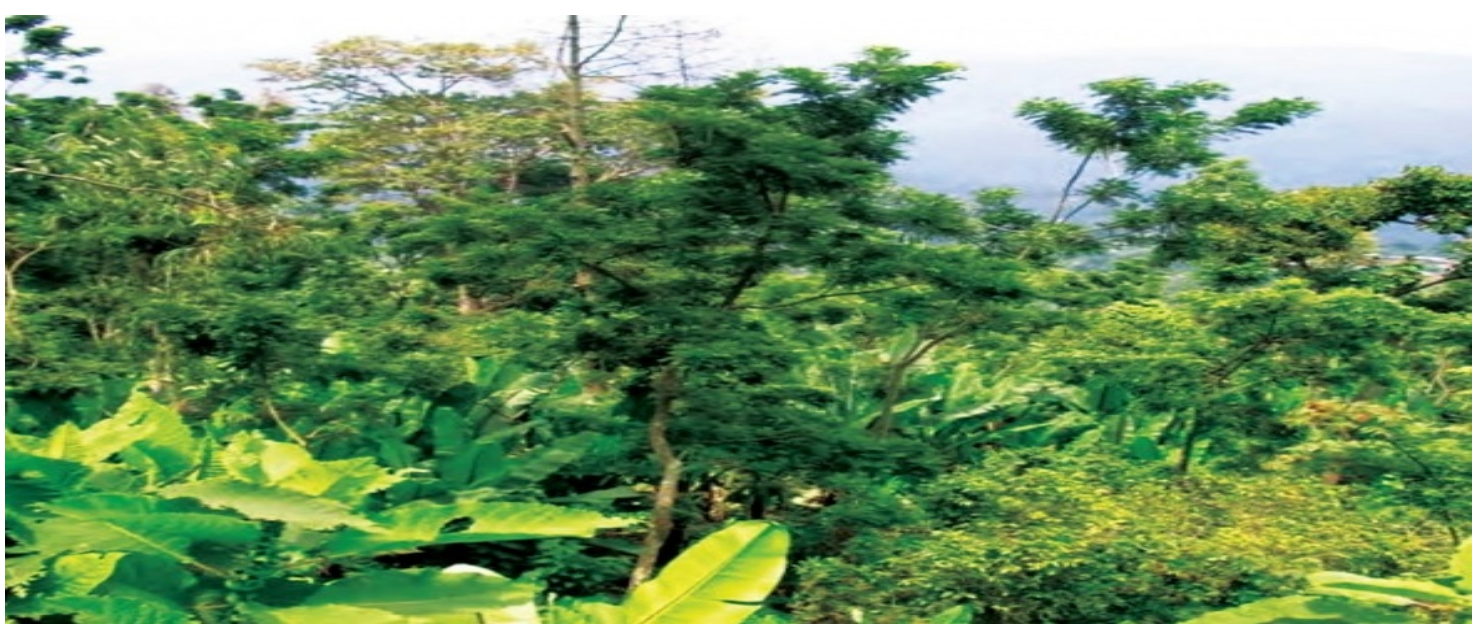

Figure 5: Gedeo multistory agroforestry based system (Basheset al,2013 )

The system is known as parkland agroforestry. Parklands are the traditional agroforestry systems of central and northern Ethiopia where naturally growing, valuable trees are protected and nurtured on cropping and grazing lands. The second type of agroforestry system is the perennial-crop-based home garden agroforestry systems, in which perennial crops, fruits, spices, vegetables, trees, etc. are grown in the home garden. The prototype perennials are enset and coffee t. Such a home garden agroforestry system is common in the south and southwestern highlands. The third type of agroforestry system in Ethiopia is woodlot agroforestry. An example of woodlot agroforestry is the bamboo-based agroforestry in the Adware zone (Madalcho\&Tefera 2016).

\subsection{Landholding}

As the area of the gardens is limited, the activities undertaken inside the gardens could be minimal. Because of the limited area, the number of species is lower. It is recommended to have a larger area to support a higher number of laborers, diversify tree and crop species and increase the numbers of products providing income. The proportionality of home garden size to the number of family members varies with various agricultural systems. The average size of a home garden, in several tropical and sub-tropical regions, typically is much less than a hectare (Das, 2013; Kumar, 2015; Rana et al., 2016; Abebe, 2005).

Mesfin et al. (2014) stated that the maximum and minimum size of home gardens encountered was between 0.05 and 0.25 ha with the average size being between 0.06 (Abebe\&Bongers, 2012) and 0.7 ha.(Tolera, Alfas, Yemenis, \&Karltun, 2008). In the south-central highlands of Ethiopia, their size is $0.35,0.27$, and 0.12 ha for rich, medium, and poor households, respectively. A study for the Food and Agriculture Organization of the United Nations (FAO) estimated that to grow three to five trees, a household would need at least $167 \mathrm{~m} 2$ of land. It may be mentioned here is that very often such small-sized land-use systems with subsistence levels of monocropping are not viable, particularly in rural ecosystems (Geiger, 2014). The author's (Plants, 2013) study of Wolyta home gardens further suggested that the gardens providing for different practices are declining, including their use for shade as well as for suitable places for conducting ceremonies and get-togethers for the villagers during social gatherings and religious holidays when coffee and snacks (of roasted grains) and bread maybe served.

Gebrehiwot's (2013) study in the Sidama zone revealed that the incomes that were generated from the home garden in which women were the laborers had been governed by themselves. However, while the land-use change from home garden to crop production that generated income will be used by males since the labor force to produce crops is typically male. To encourage marriage, females show their ability to manage the home garden in their home.If they do not have a home garden, they will not have less opportunity for marriage (Gebrehiwot, 2013; Gebrehiwot et al., 2018; Tsegaye, 2002). Simultaneously, the species diversity in home gardens will be reduced as home gardens shift to monoculture crop production. Decision-makers and other related stakeholders have to take this issue into account when stating policies and devising strategies.

Even though the income from cash crop production contributes to spending for goods besides food, the household members may not have sufficient access to food. On the other hand, Plants' (2013) study describes the surplus product that was obtained from the home garden and sold at the market can help to satisfy the need for a balanced diet among household members

Peoples' intention to have a larger farm size garden has not been yet studied. Even though in some parts of the country this agroforestry practice has been adopted well, dispersing it to other parts with similar potentials is limited. The way to adopt or scaleup this new technology for other areas can be facilitated utilizing integrating it with other stakeholders' concerns and programs for dealing with the poor living status of farmers in Ethiopia 


\section{Conclusion}

HomegardensAgroforestry systemsare common in most tropical countries and they play a vital role in supporting households in many diverse ways, including the provision of food, fuelwood, building materials, and fodder for livestock, and income. This review aimed to assess information diversity and benefit socioeconomic contributions ofhomegarden agroforestry practice and to the household in Ethiopia. Proper management and Importance of home gardensagroforestry system has a great potential for Benefitcontribution socioeconomic, improving food security, biodiversity conservation, and provides for ecosystem services in the different literature. The present review indicates that there is a knowledge gap in the cultivation, conservation, and management of useful plant species in the home gardeners. Therefore, incorporating indigenous knowledge with scientific management and conservation of useful plant species, creating awareness of adopted and non adopted household among home gardenagroforestry for rural and urban dwellers, will promote urban agriculture in Ethiopia in general. Home gardening is a time-tested example of sustainable, multispecies, agroforestry land-use, practiced as a subset of the farming system, predominantly in lowland humid tropics. The high structural and floristic diversity of tropical home gardens is a reflection of theuniquebiophysical environmentandsocio-cultural factors under which they exist. As assemblages and repositories of a vast number of plants in small parcels of land around the home in direct and constant interaction with its owners, the home gardens fulfil specific economic, social, andculturalneeds ofthe individual owners and provide biological conservation, carbon sequestration, and such other intangible yet valuable besets to the society. With their ecological similarities to naturalforest ecosystems, home gardens act as insurance against pests and disease outbreaks (although septic data are lackingto supportthis conjecture), and by providing a variety of goods and servicesforwhichpeoplemayotherwise dependonor destroy forests, they act as a buffer against the strong pressures on natural forests.Agroforestry systems have contributed to biodiversity conservation and the production of diverse products to maintain the livelihood of the farming households in Ethiopia. In particular, it has served as a mainstay in the highly populated area. The influence of markets, land scarcity, and population pressure have accelerated a shift from subsistence home garden agroforestry to market-based farming. With the expectation of producing more food to feed the rapidly growing population using high inputs and monocropping systems, farmers are inclining toward producing one or two crops in a monocropping system by abandoning the traditional agroforestry system. Also, little attention has been paid to IK. The rate at which IK is transferred from elders to the younger generation is slowing down. The pressure from untested and ever-expandmono-crop farming systems and the dying out of IK together have facilitated the decline of agroforestry in quality and quantity. If this decline is not quickly and properly addressed, Ethiopia will lose a traditional agroforestry system, ultimately leading to great losses in agrobiodiversity and socioeconomic calamity.

\section{Recommendation}

Homegarden Agroforestry practices which are very common carry out in Ethiopia is a very important resource for the production, productivity, conservation of biodiversity, and other related benefits that are dependent on the existence of the system. These trees are diverse ranging from native to exotic ones and have different densities per hectare; the tree species vary from place to place depending on factors such as; interest of farmers, land size, agro-climatic condition, characteristics of the species, etc. The associated component diversity of Homegarden agroforestry enhances the livelihood of the local people by providing socio-economic and agro-ecological service than non-tree based garden; important to adapt to climate change or climate-related stress (drought). The government should work jointly with the local farmers in changing the monocarp land-use system to a mixed agroforestry system for climate change adaptation

Enset-AF and enset-coffee-AF are more important than fruit-coffee-AF in terms of the conservation of native woody species. The proportion of native woody species is lower in the fruit-coffee-AF system, implying that the introduction of exotic fruit tree species could be a threat tothemaintenanceofnative woodyspecies. Fruitcoffee-AF has a higher basal area and stem number than enset-AF andenset-coffee-AF. Altitude and aspect affect both species richness and abundance. In effect, habitats with a higher number of ecological, conservational, and livelihood functional groups have better conservation potential. Substantial numbers of native trees on our study sites contribute to the provision of fuelwood, timber or poles, medicine, and fodder, and maintain soil fertility. These functional groups will foster the practice of maintaining native tree species and substantiates the concept of circa situmbio diversity conservation. This implies that agroforestry intervention strategies should consider use values for sustaining species in agroforestry lanscapes.Apart from the conservation of native woody species, the Multistrada agroforestry systems canalso serve to attract agro-tourism.

Different but appropriate management of Homegarden Agroforestry is very much needed for the productivity of crops and soils which could be increased by the incorporation of the appropriate use of local biodiversity resources. There are many Homegarde trees used in different corners of the country: Ethiopia and 
the most common indigenous trees found include: Faidherbia albida, Cordia a fricana,Crotonmacrostachyus, Millettiaerruginea, Ficusvasta, Ficussur,Acaciaetbaica, and Acacia lahai.There are different challenges to the parkland agroforestry practices of Ethiopia and some of them include land shortage as a result of population pressure, expansion of market-oriented products, climate change, the land tenure system, and expansion of exotic tree species at the expense of indigenous and native ones.

The practices of tree planting are very much important to enhance the tree cover in the farm fields. As a result, the policy aiming to increase tree cover should not only concentrate on large areas covered with trees but also should take into account scattered trees and small tree patches found on farm fields. Hence, there are very limited studies found so far on parkland trees of Ethiopia; there is a need for a more comprehensive analysis of the multiple benefits and services provided by parkland trees located on farmlands.

\section{ACKNOWLEDGEMENT}

In the name of GOD, the Most Graciously and the Most Merciful thanks great big, all praises to GOD. He blessed me with good health, intellectual efficiency, fully talented teachers (advisor), and sympathetic friends, whose proper guidance, consistent encouragement, and inspiration enabled me to start this senior seminar paper. I feel great pleasure and honor to express my heartiest gratitude and a deep sense of obligation to my advisor ZerihunKebebewu (Associate professior) for his keen interest, encouraging guidance, for his valuable advice, insight, and guidance from the initiation to the completion of these senior seminar paper, his open-minded views, help and valuable suggestions for the successful beginning of this senior seminar paper.

Last but not least, my deepest gratitude goes to my beloved parents, my family, my parents, and my friends who are always with me all my life for their encouragement and assistance day and night.

\section{Reference}

Abebe, T. (2005). Diversity in Homegarden Agroforestry Systems of Southern Ethiopia. Tropical ResourceManagement. doi:10.15713/ins.mmj.3 [Crossref], [Google Scholar]

Abebe, T., 2005.Diversity in home garden agroforestry systems of Southern Ethiopia.

Adekunle, V.A.J. \&Bakare, Y. (2004). Rural Livelihood Benefits from Participation in Taungya Agroforestry System in Ondo State Nigeria. Journal of Small-Scale Forest Economic, Management and Policy 3(1): Pp 131-138. [3].

Adekunle, V.A.J. (2005). Trends in Forest Reservation and Biodiversity Conservation in Nigeria.In: Environmental Sustainability and Conservation in Nigeria, Okoko, E., Adekunle, V.A.J. \&Adeduntan, S.A. (Eds), Environmental conservation and Research Team, Federal University of Technology, Akure Nigeria. Pp 82-9

Admasu, T., and Struik, P. C. (2002a). Analysis of enset (Enseteventicosum): indigenous production methods and farm-based biodiversity in major enset-growing regions of Southern Ethiopia. Agriculture and Human Values 38, 291-315

Agize, M., Demissew, S. and Asfaw, Z., 2013. Indigenous knowledge on the management of home gardens and plants in Loma and GenaBosa districts (weredas) of Dawro Zone, Southern Ethiopia: plant biodiversity conservation, sustainable utilization, and environmental protection. Int J Sci: Basic Appl Res (IJSBAR), 10, pp.63-99.

Alemu MM (2016) Indigenous Agroforestry Practices in Southern: in the case arbaminchOA Lib JOURNAL $3(12) / !-12$.

Ashley, R., Russell, D., and Swallow, B. (2006). The policy terrain in protected area landscapes: challenges for agroforestry in integrated landscape conservation. Biodiversity and Conservation 15, 663-689.

Atangana, A., Khasa, D., Chang, S. and Degrande, A., 2013.Tropical agroforestry. Springer Science \& Business Media.

Badege, B. \& Abdu, A. (undated).Agroforestry and community forestry rehabilitation of degraded watersheds on the Ethiopian highlands.In: Ethiopian Tree Fund Foundation (ETFF). Addis Ababa

Belachew W, Zemede A, Sebsebe D (2003) Ethnobotanical Study of Useful Plants in DaniioGade (HomeGardens) in Southern Ethiopia. Ethiopian journal of biological science

Bhagwat, S. A., Willis, K. J., Birks, H. J. B., and Whittaker, R. J. (2008a). Agroforestry: a refuge for tropical biodiversity? Trends in Ecology \& Evolution 23, 261-267.

Bishaw, B, Neufeldt, H, Mowo, J, Abdelkader, A, Muriuki, J, Dalle, G \&Luedeling, E 2013, 'Farmers' strategies for adapting to and mitigating climate variability and change through agroforestry in Ethiopia and Kenya', Forestry Communications Group. Edited by Davis CM, Bernart B, Dmitriev A. Corvallis, Oregon: Oregon State University.

Cromwell, E., Coper, D., and Mulvany, P.( 1999). Agriculture, biodiversity, and livelihood:

CSA (Central Statistical Authority). 1996. Population and housing census, 1994. Analytical report for the Southern Nations, Nationalities, and People's Region. Addis Ababa. 
Degefa, S., (2016)Home garden agroforestry practices in the Gedeo zone, Ethiopia: a sustainable land management system for socio-ecological benefits. Socio-ecological production landscapes and seascapes (SEPLS) in Africa, p.28.

Ecosystems and Environmental 41(2): 189-207

Edmund Merem (2005). The agroforestry systems of West Africa: The case of Nigeria. AFTA Conference proceedings.Pp 1-11

Feleke, W. (2011).Home gardens and spices of Basketo and Kafa. Southwest Ethiopia: Plant diversity, product valorization and implications to biodiversity conservation Addis Ababa University. Addis Ababa, Ethiopia

Fernandez ECM and Nair PKR. 1986. An evolution of the structure and function of tropical home gardens. Agricultural Systems 21: 279-310

Gebrehiwot, M. (2013). Recent Transitions in Ethiopian Homegarden Agroforestry: Driving Forces and Changing Gender Relations. Swedish University of Agricultural Sciences. [Google Scholar]

Gebrehiwot, M., 2013. Recent transitions in Ethiopian home garden agroforestry (Vol. 21).

Geiger, K. (2014). Characterizing the traditional tree-garden systems of southwest Sri Lanka. Tropical Resources, 34, 93-103. [Google Scholar]

Habtamu, H \&Zemede, A, 2011, 'Home gardens and agrobiodiversity conservation in Sabata town, Oromia Regional State, Ethiopia', SINET: Ethiopian Journal of Science, vol. 34, no. 1, pp. 1-16

Haile G, Lemenih M, Senbeta F, Itanna F (2017) Plant diversity and determinant factors across smallholder agricultural management units in Central Ethiopia. Agroforestry Systems. 91(4): 677-695.13

Helen Keller International/Asia-Pacific. 2010. Homestead food production model contributes to improved household food security, nutrition, and female empowerment-Experience from scaling-up programs in Asia (Bangladesh, Cambodia, Nepal, and the Philippines). Nutrition Bulletin Vol. 8 Issue 1.

HIK (Hellenkeller International /Asia-pacific) (2001). Homestead Food Production -A strategy to combat malnutrition and poverty. Helen Keller International Jakarta, Indonesia

Issue and entry points for development agencies. Overseas Development Institute, London. http://nt1.ids.ac.uk/eldis/agbio.htm.

Kabiret al 2009. Household and homegarden characteristics in southwestern Bangladesh.AgroforSyst 75:129145.

KippieKanshie, T. 2002. 5000 years of sustainability? A case study on Gedeolanduse. Ph.D. Dissertation, Wageningen University, The Netherlands

Kumar BM, Nair PKR (2006) Tropical Homegardens: A time-tested example of sustainable agroforestry. Advances in Agroforestry.

Kumar, and Nair, (2006). Tropical home gardens: a time-tested example of sustainable agroforestry. Environmental Experts S.L., Published by Springer, Netherlands. p. 377

Mekonen, Tefera (2010). Homegardensagrobiodiversity conservation in SebetaHawasWereda, Southwestern Shewa Zone of Oromia Region, Ethiopia.MSc Thesis, Addis Ababa University, Addis Ababa, Ethiopia. pp: $1-78$

Mekonnen, Kindu, Glatze, G., Sieghardt, M. and Franz, O. (2009).Soil properties under selected homestead grown indigenous tree and shrub species in the highland areas of Central Ethiopia.East African Journal of Sciences, 3(1): 9-17

Oram, P. (1993) Global Perspective on Population, Resources, and Agricultural.

Production. Keynote Paper, Proceedings of the 7th Australian Agronomy Conference

Richard Ingwe, Michael Ushiel, Felix E. Ojong, and Isaac Okeme (2009). Pursuing

Sobola, O.O., Amadi, D.C. and Jamala, G.Y., 2015.The role of agroforestry in environmental sustainability.IOSR Journal of Agriculture and Veterinary Science, 8(5), pp.20-25.

Soemarwoto O. and DesalegnRahmato. 1995. Resilience and vulnerability: Enset agriculture in Southern Ethiopia. Journal of Ethiopian Studies 28: 23-51

Tafere, S. M., \&Nigussie, Z. A. (2018). The adoption of introduced agroforestry innovations : Determinants of a high adoption rate - A case-study from Ethiopia The adoption of introduced agroforestry innovations : Determinants of a high adoption rate - A case-study from. Forests, Trees and Livelihoods, 1-20. doi:10.1080/14728028.2018.1493954 [Taylor \& Francis Online],

Tefera,2010. HomegardensAgrobiodiversity Conservation in Sebeta-HawasWereda, Southwestern Shewa Zone of Oromia Region, Ethiopia (Doctoral dissertation, Addis Ababa University).

Tesfaye, A., Wirsum, K. F., Bongers, F., and Sterck, F. (2006).Diversity and dynamics of homegarden agroforestry in Southern Ethiopia. In "Tropical homegardens: a time-tested example of sustainable agroforestry" (B. M. Kumar and M. A. Nair, eds.). Vol 3 pp.123-142.Springer, the Netherlands.

The Emanuel Miller Memorial Lecture 2006: Adoption as intervention. Meta - analytic evidence for massive catch - up and plasticity in physical, socio - emotional, and cognitive development.Journal of child psychology and psychiatry, 47(12), pp.1228-1245. 
Young, A. (1989), Agroforestry for soil conservation. Science and practice of agroforestry, 4 Wallingford, UK: CAB International and Nairobi: ICRAF, 276pp.

Young, A.(1997), Agroforestry for soil management. CAB International, Wallingford, UK and ICRAF, Nairobi,Kenya 